Proceedings

\title{
Assessment of Changes in Patterns of Human-Brown Bear Conflicts over a Decade in Ladakh, India ${ }^{\dagger}$
}

\author{
Aishwarya Maheshwari ${ }^{1, *}$, Arun Kumar A. ${ }^{2}$ and Sambandam Sathyakumar ${ }^{2, *}$ \\ 1 Department of Wildlife Sciences, College of Forestry, Banda University of Agriculture and Technology, \\ Banda-210001, Uttar Pradesh, India. \\ 2 Wildlife Institute of India, Chandrabani, Dehradun-248001, Uttarakhand, India; e-mail@e-mail.com (A.K.A.) \\ * Correspondence: aishwaryamaheshwari@gmail.com (A.M.); ssk@wii.gov.in (S.S.) \\ + Presented at the 1st International Electronic Conference on Biological Diversity, Ecology and Evolution, \\ 15-31 March 2021; Available online: https://bdee2021.sciforum.net/.
}

Citation: Maheshwari, A.; Kumar A, A.; Sathyakumar, S. Assessment of Changes in Patterns of HumanBrown Bear Conflicts over a Decade in Ladakh, India. 2021, 68, x. https://doi.org/10.3390/xxxxx

Published: date

Publisher's Note: MDPI stays neutral with regard to jurisdictional claims in published maps and institutional affiliations.

Copyright: (c) 2021 by the authors. Submitted for possible open access publication under the terms and conditions of the Creative Commons Attribution (CC BY) license (http://creativecommons.org/licenses/by/4.0/).

\begin{abstract}
Conflicts between large carnivores and shepherds constitute a major social-ecological concern across the Himalaya and affects community attitudes and tolerance toward carnivores. We assessed the extent and intensity of human - brown bear conflicts in the same villages of Zanskar and Suru Valleys, Ladakh, in the Indian Trans-Himalaya during two time periods (2001 to 2003 and 2009 to 2012) through field and questionnaire surveys. During 2001-2003, 180 families of 32 villages in Zanskar, and 232 families of 49 villages in Suru were interviewed, and during 2009-2012, 145 families of 23 villages in Zanskar and 115 families of 33 villages in Suru were interviewed. Overall, 475 (119/year) and 454 (151/year) heads of livestock were reportedly killed by brown bears, which caused economic loss of US \$9769 \pm 1172 and US \$4646 \pm 372 during 2001-2003 and 2009-2012 respectively. The surveys of 2009-2012 revealed that livestock predation in doksas (summer grazing camps) was higher (68\%) compared to the surveys carried out during 2001-2003 (42\%). This increased livestock depredation in doksas might be due to the extended stay and use of pastures by the local communities during spring and autumn. Damage to property in the form of breaking open of doors and windows by brown bear were reported during both the surveys. Economic losses and declining tolerance of people may trigger retaliatory killings of brown bear in Ladakh. We recommend compensation for livestock loss and improved husbandry practices in the conflict zones for bear-human coexistence.
\end{abstract}

Keywords: trans-Himalaya; livestock depredation; field and questionnaire surveys; Zanskar; Suru; Ladakh

\section{Introduction}

Brown bear (Ursus arctos) is the most widely distributed species among the eight species of bears (Servheen 1990, Schwartz et al. 2003, Nawaz 2007). They are distributed in most of the northern hemisphere, including the Palearctic and Nearctic regions of the world (Servheen 1990). They inhabit alpine and sub-alpine mountainous landscapes of Asia, Europe and North America. Their numbers and distribution range have contracted by more than $50 \%$ in Asia during the past century (Servheen 1990). The Himalayan brown bear (U. a. isabellinus), a subspecies that represents an ancient lineage of the brown bear (Galbreath et al. 2007), has a restricted distribution in the Greater and Trans-Himalayan regions of Jammu and Kashmir, Ladakh, Himachal Pradesh and Uttarakhand in India (Sathyakumar 2001, 2006). The brown bear occurs in subalpine forests and alpine meadows in the Greater Himalaya of Jammu and Kashmir, Himachal Pradesh and Uttarakhand, and in the cold-arid alpine scrub and meadows in the trans-Himalayan regions of Ladakh (Sathyakumar 2003, 2006). Questionnaire-based surveys by Sathyakumar (2001, 
2006) reported that brown bears are present in 23 Protected Areas (PAs) and 35 other localities throughout the north-western and western Himalayan regions of India.

In the Himalayan landscapes, local communities generate their livelihoods largely through nomadic pastoralism, horticulture and subsistence farming (Oli et al. 1994, Jaypal 2000, Maheshwari et al. 2010, Maheshwari and Sathyakumar 2019 \& 2020). However, due to increase in livestock population and consequent expansion of pastoralism into new areas that were historically natural and undisturbed lands, livestock are now more vulnerable to predation by large carnivores, which leads to retaliatory killing by local communities (Karimov et al. 2018, Dai et al. 2020). In India, brown bears are threatened due to poaching for bear parts and retaliatory killings to reduce conflicts (Sathyakumar 2001, 2006). This practice has significantly contributed to the local declines of snow leopard (Panthera uncia), wolf (Canis lupus) and brown bear populations (Jackson et al. 2001, Spearing 2002, Maheshwari et al. 2010, Can et al. 2014, Alexander et al. 2015, Maheshwari 2016, Maheshwari and Sathyakumar 2020, Dai et al. 2020).

We conducted field and questionnaire surveys in Zanskar and Suru Valleys of Ladakh, India, during two time periods viz., 2001-2003 and 2009-2012 to understand the patterns of human - brown bear conflicts in order to plan effective conservation and management actions for brown bears and their co-existence with local communities.

\section{Experiments}

\subsection{Study Area}

The Zanskar and Suru Valleys of Kargil District in the Union Territory of Ladakh (Figure 1) fall within the Trans-Himalayan biotic province (1B) of India (Rodgers et al. 2000). Topographically, the region is mountainous with vast valleys characterised by open and dry steppe vegetation indicating arid conditions. Major vegetation formations include open or desert steppe dominated by grasses, sedges and dwarf shrubs such as Ephedra gerardiana, Capparis spinosa, Salsola collina, Stipa klimesii, Leymus nutans, Eurotia ceratoides Artemisia macrocephala, Hippophae rhamnoides, Myricaria elegans and Caragana species, (Kala 2011, Maheshwari 2016). Large mammals that co-exist with brown bears in Kargil Himalaya include the snow leopard, wolf and ibex. The elevation in the study area ranges from 3400 to $7510 \mathrm{~m}$ with significant land surface under permafrost coverage (Maheshwari 2016). The climate in the study area is largely dry with extreme cold conditions throughout the region.

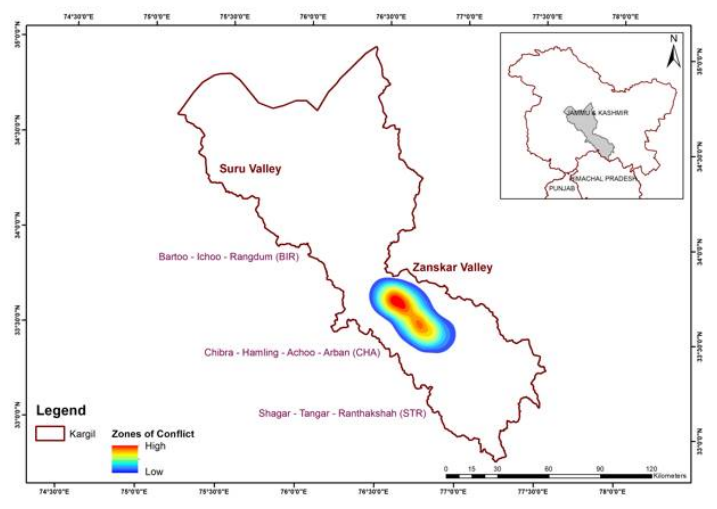

(a) 2001 to 2003

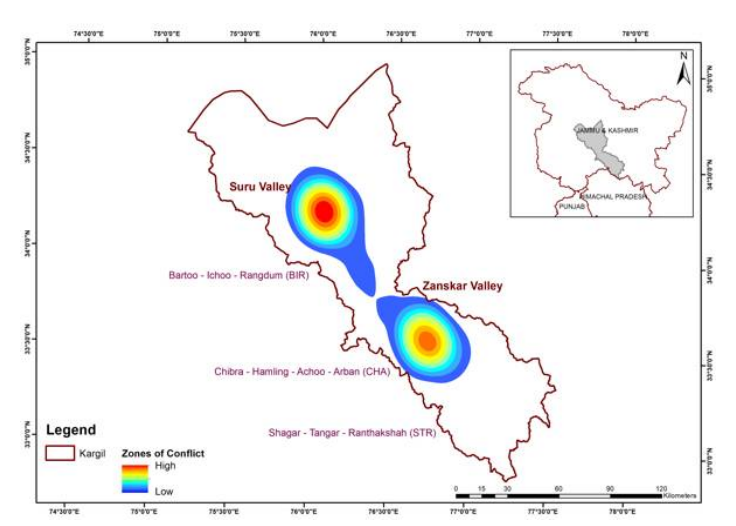

(b) 2009 to 2012 


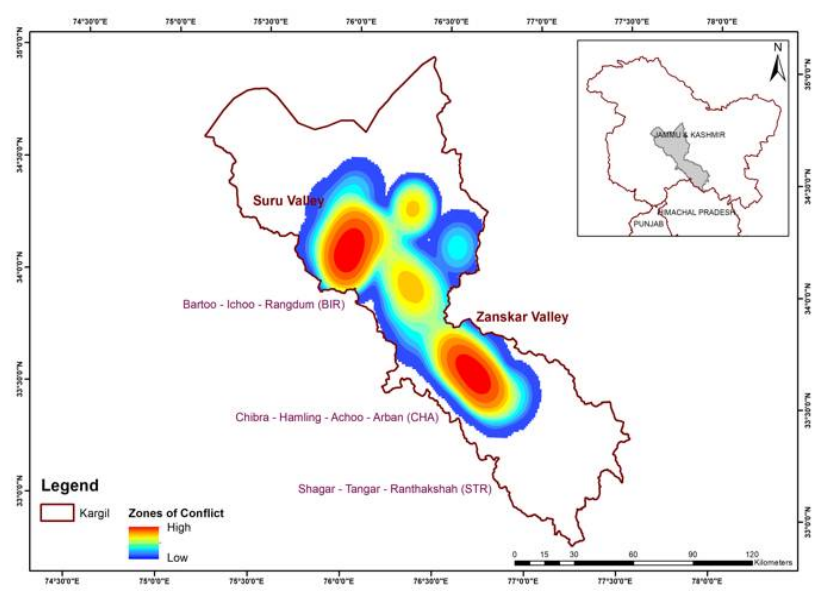

(c) Pooled time periods

Figure 1. Map showing brown bear-human conflict in Kargil through kernel distributions of the events of livestock depredation during 2001 to 2003 (a), 2009 to 2012 (b) and 2001 to 2012 (c).

The Suru Valley forms a major portion $\left(4500 \mathrm{~km}^{2}\right)$ of Kargil District and it is characterised by steep and rocky mountains, wide valleys with human habitations and agriculture/horticulture lands. Rivers Suru and Drass drain the Valley which join the Indus flowing in the north (Maheshwari 2016). The Zanskar Valley $\left(3000 \mathrm{Km}^{2}\right)$ is the region located south of Pensi La $(4400 \mathrm{~m})$ and it is characterised by large valleys with human habitations and agriculture/horticulture lands and surrounded by mountains. Zanskar river drain the valley and joins the Indus at Nimmo (Maheshwari 2016). The Zanskar Valley is bordered by the Great Himalayan high mountains to the south and west. Traditionally, the local communities are involved in subsistence farming and agro-pastoral based lifestyle, they cultivate the land along the course of the drainage system, wherever artificial irrigation from mountain streams is possible. Kargil is one of the sparsely populated regions in India and settlement pattern is just along the river valleys and few broad valleys (Maheshwari 2016). The human population in the study area is dominated by Buddhists (in Zanskar Valley) and Muslims (in Suru Valley) with human density of 8 persons $/ \mathrm{km}^{2}$ for Kargil District (Census 2011).

\subsection{Methods}

We carried out field and questionnaire surveys for 75 days during the summer months of 2001 (40 days), 2002 (20 days) and 2003 (15 days) in Zanskar and Suru Valleys to assess the extent and intensity of brown bear-human conflicts. The surveyed localities include most of the villages along the main Kargil-Padam motor road and in the side valleys of Sankoo, Umba, Rangdum, Padam and Kanji that are representative of the Zanskar and Suru Valleys. We repeated these surveys in the same villages (as it was conducted during 2001-2003) during summer months of 2009-2012 (90 field days). Informal semistructured interviews (Sathyakumar 2001, Maheshwari et al. 2014, Dai et al. 2020) were used to collect information on livestock holdings, livestock grazing patterns, status of large carnivores and livestock depredations caused by them from the villagers. During 2001-2003, 180 families of 32 villages in Zanskar, and 232 families of 49 villages in Suru were interviewed, and during 2009-2012, 145 families of 23 villages in Zanskar and 115 families of 33 villages in Suru were interviewed.

We interviewed a minimum of five families in a village and if brown bear livestock depredations were reported by even one of these five families, then we sampled at least $30 \%$ of the total families living in that village (Sathyakumar 2003). Villagers living in doksa (summer settlement) were also interviewed. To reduce and avoid overestimation of live- 
stock depredation, we employed Participatory Rural Appraisal (PRA), a standardised approach for collecting data on large carnivore-human conflict using the semi-structured interview technique of PRA (Maheshwari et al. 2014).

Understanding the Spatial Pattern of Livestock Loss and Economics of Brown Bear Predation

To understand the spatial distribution of livestock predation by brown bear, the GPS (Global Positioning System) locations of the predation cases were recorded during the surveys and kernel-density transformation were adopted to understand predation density across the study area. It provides a means to visualize point pattern to detect hotspots (O'Sullivan and Unwin 2003). Kernel-density estimation provides a map of estimates of local intensity of any spatial process from a set of observed occurrences (Bailey and Gatrell 1995). A development gradient representing the conflict intensities through varying densities of conflict was created (Worton 1989) using kernel-density tool in ArcGIS 10.5. The method begins by centring a bivariate probability density function with unit volume (i.e., the "kernel") over livestock predation locations. A regular grid is then superimposed on the data and a probability density estimate was calculated at each grid intersection by summing the overlapping volumes of the kernels. A bivariate kernel probability density estimator (i.e., a "utilization distribution") was then calculated over the entire grid using the probability density estimates at each grid intersection (Kernohan et al. 2001). The resulting kernel probability density estimator would have relatively large values in areas with many observations and low values in areas with few. We calculated the distribution using the fixed kernel estimator with least squares cross validation (LSCV) as the smoothing parameter, with a sample size $\geq 30$. This search radius (bandwidth) is computed specifically to the input dataset using a spatial variant of Silverman's Rule of Thumb that is robust to spatial outliers (Silverman 1986). Further, to understand the economic loss incurred by the locals in the form of livestock predation, we obtained the market price of the livestock and averaged it for each livestock category such as goat and sheep, cow, yak/dzo/dzomo (hybrid of cow and yak) and horse/donkey.

\section{Results}

In total, 412 respondents from 81 villages (180 respondents from 32 villages of Zanskar, and 232 respondents from 49 villages of Suru) were interviewed during 2001-2003 survey. Additionally, in Zanskar, 16 villagers living in eight doksas were also interviewed. Whereas, during second time survey (2009-2012), 145 respondents representing 23 villages of Zanskar and 115 respondents from 33 villages of Suru Valley were interviewed and a total of 20 villagers in doksas were also interviewed in Zanskar Valley.

\subsection{Livestock Holding}

The overall livestock population had increased by about 9\% (from 2001 to 2010; Table 1) which was mostly due to increase in the numbers of cattle (18\%) and sheep and goats $(10 \%)$ and the decline in the numbers of equids $(7 \%)$. Further, shepherds reported a marginal shift in the increased use of high altitude pastures (at doksa) during spring and autumn as compared to the 2001-2003 surveys.

Table 1. Livestock holdings in the brown bear habitats surveyed in Zanskar and Suru Valleys during 2001 and 2010.

\begin{tabular}{ccccc}
\hline Livestock & \multicolumn{2}{c}{ 2001 } & \multicolumn{2}{c}{$\mathbf{2 0 1 0}$} \\
\cline { 2 - 5 } & Zanskar & Suru & Zanskar & Suru \\
\hline No. of families surveyed & 180 & 232 & 145 & 115 \\
\hline $\begin{array}{c}\text { Cattle } \\
\text { (cow, yak, } d z 0-d z o m o)\end{array}$ & 1379 & 989 & 1651 & 1154 \\
\hline Sheep and goats & 1489 & 1249 & 1628 & 1389 \\
\hline
\end{tabular}




\begin{tabular}{lllll}
\hline Equids (horses/mules/donkeys) & 834 & 747 & 849 & 619 \\
\hline
\end{tabular}

\subsection{Livestock Predation by Brown Bear}

\subsubsection{1 to 2003}

The average livestock predation was $3.15( \pm 1.65)$ animals per household i.e., on average 151 livestock/annum were reportedly killed by brown bear for those sampled families. There was a significant difference in the livestock predation sites $\left(\chi^{2}=29.66 \pm 2.42, p<\right.$ $0.05)$ and majority of the incidences took place in the villages (54\%) followed by doksa $(42 \%)$ and livestock night shelters (4\%) (Table 2). Brown bears were reportedly preyed mainly on young of cow, yak and $d z o-d z o m o(52 \%)$ and goat and sheep $(41 \%)$ during summer $(63 \%)$ and to some extent in spring $(28 \%)$. Locals reported visual encounters of brown bears on livestock kills (37\%) or have confirmed it based on tracks and signs (63\%) found near kills and their caching behaviour.

Table 2. Comparison of livestock predation by brown bear at various sites in Ladakh during two time periods (2009 to 2012 and 2001 to 2003).

\begin{tabular}{ccc}
\hline Livestock Predation across Sites & 2001 to 2003 & 2009 to 2012 \\
\hline Doksas & 200 & 309 \\
\hline Villages & 257 & 145 \\
\hline Night shelter & 19 & - \\
\hline Livestock predation conflict hotspots & \\
\hline BIR & - & 173 \\
\hline STR & 208 & 281 \\
\hline CHA & 267 & - \\
\hline
\end{tabular}

\subsubsection{9 to 2012}

The average livestock predation was $4.56( \pm 2.65)$ animals per household i.e., 119 livestock/annum were reportedly killed by brown bear for the sampled families. There was a significant difference in the livestock predation sites $\left(\chi^{2}=35.46 \pm 1.98, p<0.05\right)$ and majority of the incidences took place in doksas (68\%) followed by villages (32\%) (Table 2). Sheep, goats $(54 \%)$ and young of cow, yak and dzo-dzomo (46\%) were the most common prey during summer $(66 \%)$ and spring (34\%). Locals reported more frequent brown bear visual encounters on livestock kills in Zanskar Valley (68\%) than Suru Valley (32\%).

\subsection{Spatial Patterns in Brown Bear-Human Conflicts}

\subsubsection{1 to 2003}

In Zanskar, two conflict zones were identified i.e., Shagar-Tangar-Ranthakshah areas (STR) and Chibra-Hamling-Achoo-Abran areas (CHA) (Figure 1a). The brown bears were reported to have preyed upon $6.3 \%$ (total livestock population 3301 in sampled families) and $7.9 \%$ (total livestock population 3386 in sampled families) of the livestock population of CHA and STR, respectively (Table 2).

\subsubsection{9 to 2012}

We recorded two-conflict zones viz., one in Suru (Bartoo-Ichoo-Rangdum; BIR) and another one in Zanskar (Shagar-Tangar-Ranthakshah; STR) (Figure 1b). The brown bears were reported to have preyed upon $5 \%$ (total livestock population 3450 in sampled villages) and 7.3\% (total livestock population 3840 in sampled villages) of the livestock population of BIR and STR, respectively (Table 2). 


\subsection{Trend in Brown Bear-Human Conflicts}

A kernel distribution of the conflict events determined three conflict zones viz. BIR, in Suru and CHA and STR in Zanskar Valleys in both the time periods (Figure 1c). During the period 2009 to 2012, the total livestock loss due to brown bears (including both valleys) $6.5 \%$. Of this, Zanskar and Suru reported $6.9 \%$ and $6.1 \%$ livestock loss respectively. Similarly, in 2001 to 2003, the total livestock loss due to brown bears (including both valleys), was $6.8 \%$. Of this, Zanskar and Suru reported $6 \%$ and $7.5 \%$ of their livestock loss respectively.

\subsection{Economics of Brown Bear Predation}

Locals incurred an average annual loss of US $\$ 4646 \pm 372$ in 2001-2003 and US $\$ 9769$ \pm 1172 livestock in 2009-2012 and due to brown bear depredation. The average economic loss/household was US \$32 in 2001-2003 and US \$ 105 in 2009-2012. The annual income of a rural villager in Ladakh Range from US $\$ 250$ to US $\$ 400$ (Directorate of Economics \& Statistics, J\&K. 2012, Ministry of Finance-Government of India, 2009). Of equal concern is the incidence of damage to the property by brown bear in Zanskar. In the current surveys, local communities reported imminent nature of the threat to damage private property such as windows and doors of the houses and livestock night shelters, altogether costing approximate US $\$ 1231 \pm 71$ SE.

\section{Discussion}

\subsection{Comparison with Other Brown Bear Studies}

We found that brown bear caused extensive livestock predation in the alpine meadows of Kargil Himalaya. Livestock depredations followed by damage to the properties were two of the major concerns of the local communities in the region. Both led to economic losses to the locals, therefore, possibility of retaliatory killing cannot be ruled out. Spearing (2002) reported that three brown bears were killed in Zanskar during 1998 to 2001. However, we did not encounter any such case during the study duration. For instance, in Himachal Pradesh, migratory shepherds (gaddies) often kill brown bears to reduce livestock predation (Sathyakumar 2001, Rathore and Chauhan 2007). Rathore (2008) reported that livestock depredation by brown bear ranged from $2.2 \%$ to $12.9 \%$ livestock/annum in Kugti Wildlife Sanctuary. There had not been any cases of attacks on humans by brown bear in Himachal Pradesh (Rathore 2008). However, during the 2001-03 survey, first-hand accounts of brown bear attack on humans (in 2001) was recorded from a villager in Abran village, Zanskar Valley (Sathyakumar 2003). For comparison, in Sanjiangyuan region of China, Tibetan brown bears were estimated to damage properties more significantly than livestock depredation (Dai et al. 2020). Whereas in our findings, there is a comparatively more loss (almost 132 heads of livestock annually) of livestock in Kargil. This disparity is explained by the poor guarding practices, unsupervised livestock grazing and $100 \%$ dependence on natural resources, which is commonly reported across the Indian Himalaya (Rawat 2005, Maheshwari 2016). On compensation for the damage to the property and livestock loss, $\$ 4,030,918$ was paid in Sanjiangyuan region (Dai et al. 2020) but there was no compensation reportedly received by the locals during the present study. Although up to $61 \%$ of those interviewed used no direct measures to minimize risk of damage from brown bears, we observed that most people around Zanskar were keeping dogs to guard the livestock but efficiency of such measures was limited, which are widely used probably lead to habituation to brown bear (Can et al. 2014, Ambarlı and Bilgin 2008, Sathyakumar 2001, Rathore 2008).

\subsection{Pattern of Brown Bear-Human Conflict}

We estimated a decline of 37\% (from 2001-2003 to 2009-2012) in the number of respondents who reported cases of brown bear-human conflict. Although there was $18 \%$ increase in the total number of livestock holdings by the respondents, the livestock loss to 
brown bear remained almost same. Average annual financial loss/household due to livestock predation by brown bear was $10.8 \%$ (2009-2012) and $8.9 \%$ (2001-2003) of the average per capita income for rural villagers of Ladakh during the financial year 2011-12 and 200405 respectively. (Directorate of Economics \& Statistics, J\&K. 2012, Ministry of FinanceGovernment of India, 2009). The present study also made an attempt to understand presence of brown bear with livestock predation by brown bear in the conflict zones. During 2009-12, we recorded 88 evidences of brown bear with $6 \%$ livestock loss in BIR and 31 evidences of brown bear with $9 \%$ livestock loss in STR of the total livestock population in both the conflict zones. This high number of brown bear evidences and low levels of conflict may be due to improved livestock husbandry practices in BIR. Government owned livestock (sheep and goats) were not depredated by any wild carnivore as 5-6 staff members of the Sheep Husbandry Department guarded the animals efficiently. Moreover, damage frequency seems to have increased in the summer pastures due to unsupervised grazing of the livestock, which in turn was caused by many residents either moving to big cities for better jobs or opportunities in the eco-tourism sector in Zanskar range.

\subsection{Mitigation Efforts}

On monetary compensation, we found that in the early 2000, the Department of Wildlife Protection, Jammu and Kashmir had provided compensation for wildlife depredations in Kargil District. But there had been a gap of almost 12 years after 2002 and locals had not received any compensation due to lack of funds allocation. Therefore, it seems that there was unappreciated common interest between the locals and the government. Since 2010, the Department of Wildlife Protection, Jammu and Kashmir resumed compensation schemes but approach of such schemes in the remote areas and complicated process made it cumbersome for the locals to apply for compensation for livestock loss due to wild carnivores (Maheshwari et al. 2010, Maheshwari et al. 2014).

\section{Conclusions}

We conclude that livestock guarding practices are primarily responsible for livestock loss to brown bear in the Kargil Himalaya:

- Unsupervised grazing of cattle and horses in hill slopes or nullas (streams in narrow valleys) for prolonged period as in case of Suru Valley

- Sheep and goat grazing by children in both valleys.

- Poor search effort for missing animals

- Poor construction and maintenance of traditional livestock night-shelters, food storage rooms etc.

Since, brown bear population is declining throughout most of its range in south Asia, and considering that the population is still small, has poor growth potential, and a relatively low genetic diversity (Nawaz 2007), it requires a continuous field and genetic monitoring. Maintaining and improving the connectivity with adjacent populations in Pakistan and India will be of utmost importance for its long-term survival. The causes for livestock predation in Zanskar and Suru Valleys were largely due to the existing livestock grazing and guarding practices. We propose simple measures to reduce human-brown bear conflicts and also prevent loss due to other predators: adult supervised livestock grazing at the village level and reinforced walls/doors for livestock night shelters.

Author Contributions: A.M. and S.S.K. contributed to the study design and field-work. A.M., S.S.K. and A.K.A. wrote the article. All authors have read and agreed to the published version of the manuscript.

Institutional Review Board Statement:

Informed Consent Statement:

Data Availability Statement: 


\begin{abstract}
Acknowledgments: We thank the Wildlife Institute of India (WII) and the International Association for Bear Research and Management (IBA) for providing funding support to SSK for the study (20012003) and Rufford Foundation for providing funding support to AM for the study (2009-12). We thank Jagdish, Ringchen Angdus, T. Sangay, Kazim for their assistance during the field surveys. We thank the Department of Wildlife Protection, Jammu \& Kashmir for providing permission for the study. We also acknowledge the cooperation of the people of Kargil, Suru and Zanskar during the field and questionnaire surveys. Our thanks are due to Lalit and Mukesh for their valuable comments on the draft manuscript.
\end{abstract}

Conflicts of Interest: The authors declare no conflict of interest. The founding sponsors had no role in the design of the study; in the collection, analyses, or interpretation of data; in the writing of the manuscript, and in the decision to publish the results.

\title{
Abbreviations
}

The following abbreviations are used in this manuscript:

$\begin{array}{ll}\text { PAs } & \text { Protected Areas } \\ \text { GPS } & \text { Global Positioning System } \\ \text { LSCV } & \text { Least Squares Cross Validation }\end{array}$

\section{References}

1. Alexander, J.; Chen, P.; Damerell, P.; Youkui, W.; Hughes, J.; Shi, K.; Riordan, P. Human wildlife conflict involving large carnivores in Qilianshan, China and the minimal paw-print of snow leopards. Biol. Conser. 2015, 187, 1-9.

2. Ambarl, H.; Bilgin, C.C. Human-Brown Bear Conflicts in Artvin, Northeastern Turkey: Encounters, Damage, and Attitudes. Ursus 2008, 19, 146-153.

3. Bailey, T.C.; Gatrell, A.C. Interactive Spatial Data Analysis; Longman Scientific and Technical: Harlow: Essex, UK, 1995.

4. Buchanan, J.M. Cost and Choice. In The Encyclopaedia of Public Choice; Rowley, C.K., Schneider, F., Eds.; Kluwer Academic Publishers: London, UK, 2003; pp. 454-456.

5. Can, O.E.; D'Cruze, N.; Garshelis, D.L.; Beecham, J.; Macdonald, D.W. Resolving human-bear conflict: A global survey of countries, experts, and key factors. Conserv. Lett. 2014, 7, 501-513.

6. Census of India. Provisional Population Totals; Paper 2, volume 1 of 2011. Rural-urban distribution India series 1; Office of the Registrar General and Census Commissioner: New Delhi, India, 2011. Data product 00-004-2011-Cen- Book (E).

7. Charoo, S.A.; Sharma, L.K.; Sathyakumar, S. Asiatic black bear-human interactions around Dachigam National Park, Kashmir, India. Ursus 2011, 22, 106-113.

8. Galbreath, G.J.; Groves, C.P.; Waits, L.P. Genetic resolution of composition and phylogenetic placement of the Isabelline Bear. Ursus 2007, 18, 129-131.

9. Directorate of Economics \& Statistics, J\&K. Indicators of Regional Development: Part I. Government of Jammu and Kashmir. 2012. Available online: http://ecostatjk.nic.in/publications/Regional_Indicators_2011-12_(Part_-I) (accessed on 15 March 2018).

10. Jackson, R.; Hillard, D.; Wangchuk, R. Encouraging local participation in efforts to reduce livestock depredation by snow leopard and wolf in Ladakh, India. CDPNews 2001, 4, 2-6.

11. Jayapal, R. Livestock Depredation by Wild Animals in Zanskar, Ladakh; Report submitted to Wildlife Institute of India: Dehradun, India, 2000.

12. Kala, C.P. Floral Diversity and Distribution in the high altitude cold desert of Ladakh, India. J. Sustain. For. 2011, 30, 360-369, doi:10.1080/10549811.2011.534036.

13. Karimov, K.; Kachel, S.M.; Hackländer, K. Responses of snow leopards, wolves and wild ungulates to livestock grazing in the Zorkul Strictly Protected Area, Tajikistan. PLoS ONE 2018, 13, e0208329, doi:10.1371/journal.pone.0208329.

14. Kernohan, B.J.; Gitzen, R.A.; Millspaugh, J.J. Analysis of Animal Space Use and Movements. In Radio Tracking and Animal Populations; Academic Press: San Diego, CA, USA, 2001; pp. 125-166.

15. Linnell, J.D.C.; Steuer, D.; Odden, J.; Kaczensky, P.; Swenson, J.E. European Brown Bear Compendium; Safari Club International: Herndon, VA, USA, 2002.

16. Ministry of Finance-Government of India. Public Private Partnerships in India-State Economy, 2009. Available online: http://www.pppinindia.com/state-economy-jammu\&kashmir.asp (accessed on 15 March 2018).

17. Maheshwari, A.; Takpa, J.; Sandeep, K.; Shawl, T. An Investigation of Carnivore-Human Conflicts in Kargil and Drass Areas of Jammu and Kashmir; Report submitted to Rufford Small Grant: Grant, UK, 2010.

18. Maheshwari, A.; Midha, N.; Cherukupalli, A. Participatory rural appraisal and compensation intervention: Challenges and protocols while managing large carnivore-human conflict. Hum. Dimens. Wildl. 2014, 19, 62-71.

19. Maheshwari, A. Conservation and Management of Snow Leopard and co-Predators with Special Reference of Large CarnivoreHuman Conflicts in the Select Areas of Western Himalayas. Ph.D. Thesis, Saurashtra University, Rajkot, Gujarat, India, March 2017.

20. Nawaz, M.A. Status of the brown bear in Pakistan. Ursus 2007, 18, 89-100. 
21. Oli, M.K.; Taylor, I.R.; Rogers, M.E.. Snow leopard Panthera uncia predation of livestock-an assessment of local perceptions in the Annapurna Conservation Area, Nepal. Biol. Conserv. 1994, 68, 63-68.

22. O'Sullivan, D.; Unwin, D.J. Geographic Information Analysis; John Wiley \& Sons: Hoboken, NJ, USA, 2003.

23. Rawat, G.S. Alpine Meadows of Uttaranchal. Ecology, Landuse and Status of Medicinal and Aromatic Plants; Bishen Singh Mahendra Pal Singh: Dehradun, India, 2005.

24. Rathore, B.C.; Chauhan, N.P.S. Predatory behavior and interaction of Himalayan brown bear with nomadic shepherds in PirPanjal Himalayan range, India. In Proceedings of the 18th International Conference on Bear Research and Management, Monterrey city, Mexico, 2007.

25. Rathore, B.C. Ecology of Brown Bear (Ursus arctos) with Special Reference to Assessment of Human-Brown Bear Conflicts in Kugti Wildlife Sanctuary, Himachal Pradesh and Mitigation Strategies. Dissertation, Saurashtra University, Rajkot, Gujarat, India, 2008.

26. Rodgers, W.A.; Panwar, H.S.; Mathur, V.B. Wildlife Protected Area Network in India: A Review (Executive Summary); Wildlife Institute of India: Dehradun, India, 2000.

27. Rodgers, A.R.; Carr, A.P.; Beyer, H.L., Smith, L.; Kie, J.G. HRT: Home range tools for ArcGIS, version 1.1; Ontario Ministry of Natural Resources, Centre for Northern Forest Ecosystem Research: Thunder Bay, ON, Canada, 2007.

28. Sagør, J.T.; Swenson, J.E.; Røskaft, E. Compatibility of brown bear Ursus arctos and free-ranging sheep in Norway. Biol. Conserv. 1997, 81, 91-95.

29. Sathyakumar, S. Status and management of Asiatic black bear and Himalayan brown bear in India. Ursus 2001, 12, 21-30.

30. Sathyakumar, S. Brown Bear-Human conflicts in Zanskar and Suru Valleys, Ladakh. Report submitted to Wildlife Institute of India: Dehradun, India, 2003; p. 22.

31. Sathyakumar, S. Status and distribution of Himalayan Brown Bear (Ursus arctos isabellinus) in India: An assessment of changes over ten years. Indian For. 2006, 132, 89-96.

32. Schwartz, C.C.; Haroldson, M.A.; Gunther, K.A.; Moody, D. Distribution of grizzly bears in the Greater Yellowstone Ecosystem, 1990-2000. Ursus 2003, 13, 203-212.

33. Servheen, C. The Status and Management of the Bears of the World. International Conference on Bear Research and Management. Monogr. Ser. 1990, 2, 32.

34. Silverman, B.W. Density Estimation for Statistics and Data Analysis; Chapman \& Hall: London, UK, 1986.

35. Soule, M.E.; Terborgh, J. Continental Conservation: Scientific Foundations of Regional Reserve Networks; Island Press: Washington, DC, USA, 1999.

36. Worton, B.J. A review of models of home range for animal movement. Ecol. Model. 1987, 38, 277-298.

37. Worton, B.J. Kernel methods for estimating the utilization distribution in home range studies. Ecology 1989, 70, $164-168$. 